\title{
Autonomy And Community Participation On The Implementation Of School- Based Management In The City Of South Tangerang
}

\author{
Hadiyanto, Yulianto Santoso ${ }^{a}$ Suryadi, Siti Zulaikhab \\ ${ }^{a}$ Universitas Negeri Padang, Jl. Prof. Dr. Hamka, Padang, Indonesia \\ ${ }^{\mathrm{b}}$ Universitas Negeri Jakarta, Kompleks Rawamangun Jakarta, Indonesia
}

Corresponding e-mail: hadymed@yahoo.com

\begin{abstract}
The main aim of the study is to explore the implementation of school-based management in the junior secondary schools in the city of Tangerang Selatan, Banten. More specifically, this study aims to compare the autonomy and community participation of school-based management in public and private junior secondary schools in the city of Tangerang Selatan. The population is all junior secondary schools in the city of Tangerang Selatan totaling 151 schools, while the sample is taken respectively 46 public and private schools. The instrument used in this study is a multiple-choice questionnaire that had been tested for validity and reliability. Data were analyzed using T-test. The results indicate that in general the implementation of the principles of school-based management in Private Junior Secondary Schools is higher (2.62) than Public Junior Secondary Schools (2.45). However, the difference of the implementation of school-based management principles statistically is not significant. Based on the results of the study, it is suggested that the Indonesian government has to improve the autonomy of the schools and empower community participation to achieve better school-based management, and to revise the government regulations that prohibit community participation.
\end{abstract}

Keywords: school-based management, autonomy, community participation, junior secondary schools

\section{INTRODUCTION}

Development of human resources in Indonesia is still a must to catch up from other developed countries. However, efforts to improve the capability of human resources in Indonesia to date still reap criticism and challenges. UNDP data shows that in 2015, Indonesia's HDI is better than in previous years, which is 0.689 , but still in the order of 113 out of 188 countries $^{[1]}$. The data shows that Indonesia's HDI from 1980 continued to rise above Vietnam, but still remains below Thailand. This indicates that the Indonesian government still need to improve the efforts of human resource development in the field of education.

The main challenges facing the nation of Indonesia in the implementation of education, including: 1) The low quality and accountability of the implementation of education, 2) Management education has not been effective and efficient, and 3) The budget of education development has not been adequate $^{[2]}$. The quality of education is greatly influenced by the ability of the State to provide education costs, the higher the cost of education in a country, the better the performance of its national education, and vice versa ${ }^{[3]}$.
Some efforts have been made by the Government of Indonesia to improve education implementation by improving the laws and regulations in education at the central and regional levels, continuously updating the curriculum, doubling the education budget, completing educational facilities and infrastructure, improving the quality of educators and educational staff, and improve the quality of education management. Especially in improving education management, according to Nandika ${ }^{[4]}$, is done by improving the autonomy and decentralization of education management in education units effectively and efficiently, transparently, responsibly, accountably, and participatively.

Efforts to improve the implementation of education has actually been driven by various countries that have implemented a model of schoolbased management. This school management model has been implemented in countries such as Canada, Australia in the $1970 \mathrm{~s}^{[5]}$ and in the United States, New Zealand from the $1980 \mathrm{~s}^{[6]}$, Hongkong, Chile, China, Germany, Poland, Russia, Uganda and Zimbabwe ${ }^{[7]}$. There are two primary keys in SBM according to Levacic, namely school autonomy and community participation in decision making ${ }^{[8]}$. 
School Based Management in Indonesia was introduced starting in 1999 under the name of School-Based Quality Improvement Management ${ }^{[9]}$, which is the forerunner of SBM implementation in Indonesia ${ }^{[10]}$. The juridical implementation of School Based Management in Indonesia was only implemented in 2003 based on Article 51 of Law Number 20 of $2003^{[11]}$ and article 49 of Government Regulation Number 19 of 2005 on National Education Standards ${ }^{[12]}$. In view of Indriyanto, SBM can be implemented through to school (school approach), community (community approach) and through District Education Office (district approach) [13].

Implementation of SBM is considered positive because SBM can spur the potential of schools to perform better ${ }^{[14]}$. The study conducted by Umaedi $^{[15]}$ shows that most $(56.28 \%)$ of schools that are piloting SBM are implemented with good management despite poor economic conditions, and $30.34 \%$ are implemented with good management under favorable economic conditions. In addition, Watson said, that SBM can: 1) improve the quality of graduates, and 2) increase opportunities for local decision-making ${ }^{[16]}$. According to Coleman, SBM can improve the effectiveness and efficiency of financing ${ }^{[17]}$. So according to Rodrigue ${ }^{[18]}$, Ogundele and Adelabu ${ }^{[19]}$, SBM can improve teacher quality, so as to improve student achievement. In Suryadi's view, school-based management intends to "return" the school to its owner, the community, who is expected to feel fully responsible for the education held in schools ${ }^{[20]}$.

The study of the implementation of school-based management, particularly autonomy and community participation in education provision in Indonesia compared with some countries such as Guatemala, New Zeland, Qatar and the United States, is reportedly not optimal ${ }^{[21]}{ }^{[22]}$, as stated in the following figure.

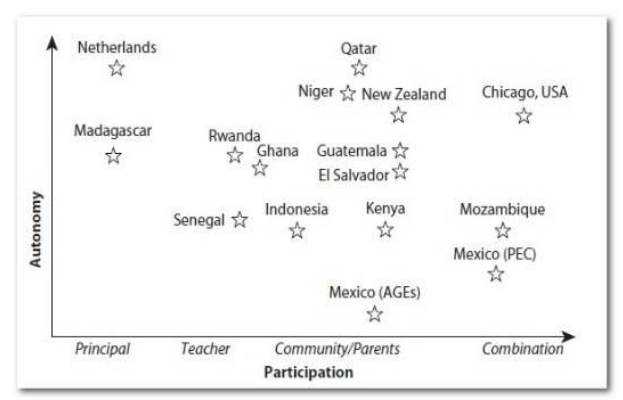

Figure 1. Level of Autonomy and Participation in SBM Implementation in Indonesia and Various Countries
Unlike the supporters of SBM implementation, ERIC Development Team ${ }^{[23]}$, and Caldwell ${ }^{[24]}$ are not yet fully convinced by SBM. This is in line with SBM in Indonesia is still tainted by in-efficiency cases and even corruption by education managers in districts/municipalities, schools and even in the community. Some mass media have written about 'Implementation of School-Based Management is Prone to Corruption' ${ }^{[25]}$, 'Principal is the Main Actor of School Operational Fund (BOS) Fraud' ${ }^{\text {[26] }}$, 'BOS Funds Deviation Happened due to Regulation Violation $^{[27]}$. Many school principals are being chased by unprofessional journalists, so the implementation of MBS into fertile fields of corruption $^{[28]}$. Bandur ${ }^{[29]}$ also shows that the implementation of school-based management in Indonesia has not been completely smoothly because there are still unavoidable problems. More details, Mustiningsih mentioned that among the problems faced in the implementation of SBM related to financial management is the problem of preparing RKS and RKAS, extracting sources of funding, bookkeeping, transparency and accountability, and lack of monitoring, evaluation and reporting ${ }^{[30]}$.

Since 2003, the Government of Indonesia has introduced and fostered school based management through the International Standard School (RSBI) program, National Standard School (SSN) ${ }^{[31]}$, which ended because the Constitutional Court sessions suspended the program ${ }^{[32]}$. Beginning in 2005 Directorate of Junior Secondary School Development, Ministy of Education and Culture implemented a School Based Quality Improvement Program, which is an adoption of Regional Education Development and Improvement Program (REDIP) by Japan International Cooperation Agency (JICA) in Bogor District, and Bekasi, West Java and District of Tangerang, Banten Province. Since 2007, the program has continued in Bekasi City, South Tangerang City, Tangerang City, and Bandung City until $2015^{[33]}$.

Implementation of school-based management is mandated by Law Number 20 Year 2003, and other derivative regulations, then the instruction of SBM implementation is for all schools in Indonesia. Thus, all schools in Indonesia must implement the principles of school-based management as mandated in legislation. Nevertheless, Danim ${ }^{[34]}$ emphasized that the implementation of SBM for improving school performance and improving the quality of students' learning outcomes in schools still needs to be tested for implementation in the field. Therefore, the purpose of this study is to know the implementation of school-based management related to: autonomy, and community participation in public and private secondary schools in South Tangerang City. 
2

\section{RESEARCH METHODS}

The study was conducted using a comparative quantitative approach, comparing the implementation of SBM in public schools and private schools in the city of South Tangerang. Data were collected by using questionnaires that have been tested for their validity and reliability. The population of research is all public and private Junior Secondary schools in South Tangerang City as many as 151 schools, while the sample is 46 SMP Negeri and SMP Private in South Tangerang City. The data was analysed by using T-test. To find out how high school autonomy and community participation in SBM, the criteria used are the scores of $3.26-4.00=$ very high, the score of $2.51-3.25=$ high, the score $1.76-2.50=$ medium, and the score $1.00-1.75=$ low

\section{RESULTS}

\subsection{Autonomy of School Management}

The result of data processing shows that the autonomy of education in state junior secondary schools in South Tangerang city (2.53) is lower than in private junior secondary schools (2.80). However, the difference is not statistically significant. In general, the autonomy of education in public and private junior secondary schools in South Tangerang City (2.67) is included in the high category. Visualization of comparison of autonomy of public and private schools in South Tangerang City as shown in following graph.

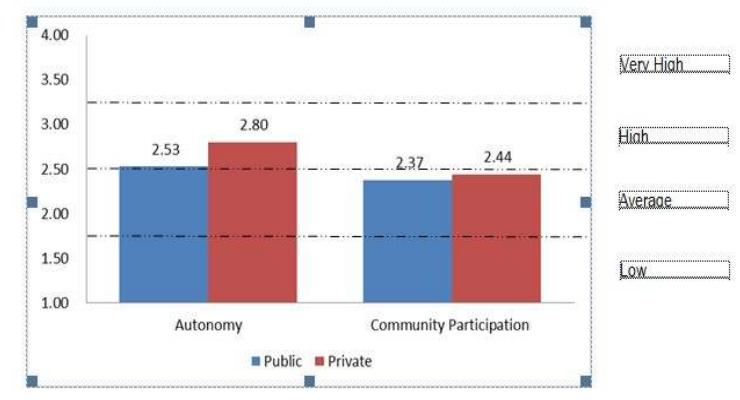

Graph 1. Comparison of Autonomy and Community Participation in School Based Management in Public and Private Junior Secondary schools in Tangerang Selatan City

\subsection{Community Participation of School Management}

Community participation in the implementation of public junior secondary schools in South Tangerang City (2.37) is lower than that in private junior secondary schools (2.44). However, the difference in community participation is statistically insignificant. Community participation in public and private junior secondary schools in South Tangerang City (2.41) is categorized as medium and close to high, as set out in Graph 1.

Of the two principles, the implementation of school-based management at private schools in general (2.62) is higher than that of public schools (2.45). Visualization of comparison of autonomy and community participation in the implementation of public junior secondary schools with private junior secondary schools in South Tangerang City as shown in Graph 1.

\section{DISCUSSION}

Implementation of the principle of autonomy and community participation in public and private junior schools visually seems different, but the differences are not statistically significant. The absence of difference is actually a question because private junior schools should have more freedom in empowering the potential of the community to improve the autonomy and increase community participation in developing schools of all potential schools. On the other hand, for public schools it is bound by various regulations that limit autonomy and community participation.

The absence of differences between public schools and private schools in terms of autonomy and community participation in South Tangerang City, according to the researchers because of the influence of Regulation of Mayor of South Tangerang City Number 61 of 2010 on the prohibition of community participation ${ }^{[35]}$. In addition, school principals and the community were puzzled by the rapidly changing school management rules. In the following year, the Indonesian Government issued the Ministry Regulation Number 60 of 2011 on the Prohibition of Tuition Fee on Elementary and Junior Secondary schools ${ }^{[36]}$, where public schools are not allowed to collect tuition fees from the community. In 2012, the Indonesian Government issued the Regulation of the Ministry of Education and Culture Number 44 of 2012 on the Charges and Donations of Education Tuition on Basic Education. In this last government regulation, community is allowed to contribute education funds to schools through school committees as long as they are managed transparently and accountably ${ }^{[37]}$. 
However, since these schools are located in urban areas, the Mayor Regulation of South Tangerang City that eventually becomes the role model that greatly limits the participation of the community in the implementation of education. In addition, the headmaster did not want to take the risk of using community participation because it is very sensitive for the community to make the issue that the principal deliberately receives and corrupt funds from the community.

According to the researcher, the Mayor Regulation of South Tangerang City Number 61 of 2010 needs to be reviewed, replaced by Mayor regulation that allows the community to participate without any prohibition. This is in accordance with Ministry of Education and Culture Number 44 of 2012 which distinguishes between levies and grants. In addition, Ministry of Education and Culture Number 75 of 2016 on School Committees ${ }^{[38]}$, has assigned tasks to school committees to raise funds and other educational resources from communities both individuals/organizations/businesses/ industries and other stakeholders through creative and innovative efforts. The Government Regulation Number 17 of 2010 on Management and Administration of Education regulates the participation of the community in the implementation of education ${ }^{[39]}$.

On the other hand, the slogans of the governors, the disproportionate mayors in promising free education should be omitted, as it entraps community ${ }^{[40]}$. The community should be given a broader understanding, that the free education promised by these officials is not all enough to implement the process of qualified education management. BOS provided by the central government is sufficient for operational costs only.

\section{CONCLUSION}

Based on data analysis and discussion that have been done in the previous section, the conclusion of the study as follows. The autonomy of education management in private junior secondary schools (2.53) is higher than that in public junior secondary schools (2.80) in South Tangerang City. However, the difference was not statistically significant. The autonomy of education in public and private junior secondary schools in South Tangerang City (2.67) is categorized as high.

Community participation in private junior secondary schools (2.44) is higher than that in public junior secondary schools (2.37) in South Tangerang City. However, the difference in community participation is statistically insignificant. Community participation in public and private junior secondary schools in South Tangerang City (2.41) is categorized as medium and close to high.

\section{RECOMMENDATION}

Based on the conclusion, as well as discussion of research results, then some suggestions that can be raised include:

Although generally the autonomy of education management in public and private junior secondary schools in South Tangerang City has been categorized in the high category, District Office of Education in South Tangerang City still need to further improve the principle of school autonomy. School autonomy can still be implemented in all areas of education management, such as school finance, curriculum and learning implementation, student affairs, school facilities and infrastructure, and extra-curricular activities.

Community participation in both public and private schools is still in the medium category, close to high. To that end, the District Office of Education, and even Mayor should be wiser to give parents the opportunity to participate in educational funding that has been agreed with the School Committee, as well as participation in the supervision of the educational process. Mayor's regulations that prohibit community participation should be revised and harmonized with higher regulations, such as with Ministry of Education and Culture regulation Number 44 of 2012 on Tuition and Education Fee Contribution on Basic Education Unit, Ministry of Education and Culture regulation Number 75 of 2016 on School Committee, and Government Regulation Number 17 of 2010 on Management and Implementation of Education in which regulate community participation. This should also be followed with the high transparency and accountability of each school principal and school committee, so that community confidence in the school is better than it has been.

\section{REFERENCES}

[1] UNDP. Indeks Pembangunan Manusia Indonesia Meningkat tapi Kesenjangan Masih Tetap Ada. (Indonesia's Human Development Index Rises But Gaps Still Remain). http://www.id.undp.org/content/ indonesia/id/home/presscenter/pressreleases/201 7/03/22/indonesia-s-human-development-indexrises-but-inequality-remains-.html.

[2] Nandika, Dodi. 2007. Pendidikan di Tengah Gelombang Perubahan. (Education in the Midst of Changes). Jakarta: LP3ES. p. 5. 
[3] Supriyoko, 2004. Pendidikan Manusia Indonesia. (Education of Indonesian Human). Jakarta: Kompas. pp. 420-421.

[4] Nandika, Dodi. 2007. Pendidikan di Tengah Gelombang Perubahan. (Education in the Midst of Changes). Jakarta: LP3ES. p. 7.

[5] Abu-Duhou, Ibtisam. 1999. School Based Management. Paris: International Institute for Educational Planning, United Nations Educational, Scientific and Cultural Organization. P. 36

[6] Brady, Laurie, 1992. Curriculum Development. New York: Prentice Hall. P. 4.

[7] Cheng, Y. Cheong. 1996. School Effectiveness \& School-based Management, a Mechanisme for Development. London: Falmer Press. P. 44

[8] Levacic, Rosalind. 1995. Local Management of School Analysis and Practice. Buckingham: Open University Press. P. 3.

[9] Umaedi, Hadiyanto, Siswantari. 2015. Manajemen Berbasis Sekolah (School-based Management). Jakarta: Penerbit Universitas Terbuka. P. 1.14.

[10] Kementerian Pendidikan Nasional Republik Indonesia. 2010. Era Mutu Sekolah Menengah Pertama. (Secondary School Quality Era). Jakarta: Kementerian Pendidikan Nasional. P. 223-250.

[11] Republik Indonesia. 2003. Undang-Undang Republik Indonesia Nomor 20 Tahun 2003 tentang Sistem Pendidikan Nasional (Law of the Republic of Indonesia Number 20 of 2003 on National Education System)

[12] Republik Indonesia. 2005. Peraturan Pemerintah Nomor 19 Tahun 2005 tentang Standar Nasional Pendidikan (Government Regulation Number 19 of 2005 on National Education Standards).

[13] Indriyanto, Bambang. 2003. 'School-Based Management: Issues and Hopes toward Decentralisation in Education in Indonesia', paper presented at the Third International Forum on Education Reform: Education Decentralization Revised: School Based Management, September 8-11, 2003, Bangkok, Thailand. P. 3.

[14] Arifin, Imron., 2002. Strategi dan Implementasi Desentralisasi Pendidikan di Sekolah Dasar. Studi Kasus MI Jenderal Sudirman Malang (Strategy and Implementation of Decentralized Education in Primary Schools.
Case Study in Islamic Primary School Sudirman General Sudirman, Malang). Malang: Dinas Pendidikan Kota Malang. P. 67.

[15] Umaedi, 2004. Manajemen Mutu Berbasis Sekolah/Madrasah (MMBS/M), Mengelola Pendidikan dalam Era Masyarakat Berubah. (Quality Management Based School / Islamic School, Managing Education in a Changing Communities Era). Jakarta: Center for Education Quality Management. P. 245-246.

[16] Watson, Hugh. 2004. Report on Evaluation of School Based Management. ACT Department of Education and Training. P.6.

[17] Coleman, P. 1984. Improving Schools by School-based Management. McGill Journal of Education, Vol.19 No.l (Winter 1984).

[18] Rodriguez, T. A. and Slate, J. R.. Site-Based Management: A Review of the Literature. Kansas City: University of Missouri.

[19] Ogundele J. A., and Adelabu, M. A. Improving Pupils Quality through Community Advocacy: The Role of School-Based Management Committee. The Journal of International Social Research. Volume 2 / 8 Summer 2009.

[20] Suryadi, Ace. 2003. Dewan Pendidikan dan Komite Sekolah: Mewujudkan Sekolah-Sekolah yang Mandiri dan Otonom (Board of Education and School Committee: Realizing Independent and Autonomous Schools). Jakarta: Depdiknas. P. 3.

[21] Gertler, P., Patrinos, A., M. R. Codina, Methodological Issues in the Evaluation of School-Based Management Reforms. gertler@haas.berkeley.edu. Diakses 12 Februari 2016. P. 25.

[22] Osorio, F.B, Fasih, T, Patrinos, H.A, Santibanez, L.,2009. Decentralized DecisionMaking in Schools, The Theory and Evidence on School-Based Management. Washington DC: The World Bank. P. 25.

[23] ERIC Development Team. School-Based Management and Student Performance. ERIC Digest, Number 62. Hh. 1-7. www.eric.ed.gov. Diakses 16 April 2017.

[24] Caldwell, B. J. 2005. School-based Management. Paris: The International Institute for Educational Planning (IIEP).

[25] Suara Pembaruan, 1 Desember 2003, 'Pelaksanaan Manajemen Berbasis Sekolah Rawan Korupsi' (Implementation of School Based Management Prone to Corruption). 
[26] Madina Pos, 30 Juni 2009. 'Kepala sekolah Aktor Utama Penyelewengan Dana BOS' (Principal is Main Actor of BOS Fund Fraud').

[27] CNN Indonesia, 21 Mei 2016. 'Penyimpangan Dana BOS Terjadi Karena Pelanggaran Regulasi' (BOS Funds Deviation Happened due to Regulation Violation).

[28] Suparlan. 2013. Manajamen Berbasis Sekolah, dari Teori sampai dengan Praktik (School Based Management, from Theory to Practice). Jakarta: Bumi Aksara. Pp. 55-56.

[29] Bandur, Agustinus. 2009. The Implementation of School-Based Management in Indonesia: Creating conflicts in regional levels. Journal of NTT Studies 1 (1) 2009. P 24.

[30] Mustiningsih. 'Masalah Implementasi Manajemen Berbasis Sekolah di Sekolah Dasar' (Problems of Implementation of School Based Management in Primary Schools'). Manajemen Pendidikan. Vol. 24 Nomor 6 September 2015. pp. 498-505.

[31] Kementerian Pendidikan dan Kebudayaan Republik Indonesia. 2013. SMP dalam Angka (Junior Secondary Schools in Figures). Jakarta: Kementerian Pendidikan dan Kebudayaan. Pp.70-74.

[32] Suyanto dan Suhardi. 2013. Hidup Mati Rintisan Sekolah Bertaraf Internasional, Boleh Bubar, Virus Kualitasnya Tetap Menyebar. (Living and Dead of Stubs of International School, Disbandable, Virus of Quality Remains Spreading). Jakarta: Kemdikbud. Pp. 161-183.

[33] Direktorat Pembinaan SMP. 2016. Petunjuk Teknis Penyaluran dan Pemanfaatan Bantuan Pemerintah untuk Program Peningkatan Mutu Berbasis Sekolah (PPMBS). (Technical Guidelines for the Distribution and Utilization of Government Assistance for School Based Quality Improvement Program). Jakarta; Dit PSMP. P.17.

[34] Danim, Sudarwan. 2008. Visi Baru Manajemen Sekolah dari Unit Birokrasi Ke Lembaga Akademik. (New Vision of School Management from Bureaucracy Unit to Academic Institution). Jakarta: Bumi Aksara. P. 7.

[35] Walikota Tangerang Selatan. Peraturan Walikota Tangerang Selatan Nomor 61 Tahun 2010 tentang Larangan Partisipasi Masyarakat. (Regulation of Mayor of South Tangerang City Number 61 of 2010 on the prohibition of community participation). Tangerang Selatan.
[36] Menteri Pendidikan dan Kebudayaan Republik Indonesia. 2011. Peraturan Menteri Pendidikan dan Kebudayaan Republik Indonesia Nomor 60 Tahun 2011 tentang Larangan Pungutan Biaya Pendidikan pada Sekolah Dasar dan Sekolah Menengah Pertama. (Ministry Regulation Number 60 of 2011 on the Prohibition of Tuition Fee on Elementary and Junior Secondary schools).

[37] Menteri Pendidikan dan Kebudayaan Republik Indonesia. 2012. Peraturan Menteri Pendidikan dan Kebudayaan Republik Indonesia Nomor 44 Tahun 2012 tentang Pungutan dan Sumbangan Biaya Pendidikan pada Satuan Pendidikan Dasar. (Ministry of Education and Culture Regulation Number 44 of 2012 on the Charges and Donations of Education Tuition on Basic Education).

[38] Menteri Pendidikan dan Kebudayaan Republik Indonesia. 2016. Permendikbud Nomor 75 Tahun 2016 tentang Komite Sekolah (Ministry of Education and Culture Regulation Number 75 of 2016 on the School Committee).

[39] Republik Indonesia. 2010. Peraturan Pemerintah Nomor 17 Tahun 2010 tentang Pengelolaan dan Penyelenggaraan Pendidikan (Government Regulation Number 17 of 2010 on Management and Implementation of Education).

[40] Mujiran, P. 2009. 'Menyoal Pendidikan Gratis' (Questioning Free Education). Suara Pembaruan, 6 Mei 2009. 